\title{
EVOLUÇÃO GEOLÓGICA DO DOMÍNIO INTERNO DA FAIXA PARAGUAI NA REGIÃO DE NOVA XAVANTINA, LESTE DE MATO GROSSO
}

\author{
GEOLOGIC EVOLUTION OF THE PARAGUAY BELT IN NOVA XAVANTINA AREA, EASTERN \\ MATO GROSSO STATE, BRAZIL
}

\section{Mariarosa FERNANDES DE SOUSA ${ }^{1}$, Carlos Humberto da SILVA², Ana Cláudia DANTAS DA COSTA ${ }^{2}$}

Instituto Federal Goiano, Campus Avançado Catalão. Av. Vinte de Agosto, 410 - St. Central, Catalão - GO.

E-mail: mariarosaifgoiano@gmail.com

Universidade Federal do Mato Grosso, Faculdade de Geociências. Avenida Fernando Corrêa da Costa, 2367 - Bairro Boa

Esperança. Cuiabá, MT. E-mails:chsilva2@yahoo.com.br; anacos@gmail.com

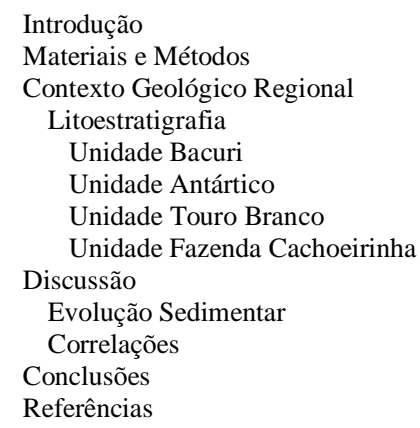

RESUMO - O mapeamento geológico realizado na porção leste da Faixa Paraguai, região de Nova Xavantina (MT), possibilitou a individualização de quatro unidades litoestratigráficas informais: (i) Bacuri: composta por formações ferríferas e metacherts bandados; (ii) Antártico definida por litotipos arranjados em ciclos de fácies heterolíticas de filito quartzoso, mármore, filito calcífero, metacórseos, metaconglomerado, metassiltito e metagrauvaca, exibindo acamamento gradacional, associado a laminações planoparalelas, cruzadas e convolutas, além de estratificações em lentes, que refletem uma deposição controlada por processos mistos (ondas e marés); (iii) Touro Branco, representada por metarenito e quartzito com grande maturidade composicional, estratificações planares e cruzadas tabulares de baixo ângulo, além de marcas onduladas e de erosão; (iv) Fazenda Cachoeirinha, marcada por filitos laminados homogêneos. As informações levantadas sugerem que estas rochas foram depositadas em um ambiente marinho transicional, formado em um mega ciclo transgressivo que termina por uma progradação em um ambiente marinho distal, que em direção ao topo e lateralmente vai se tornando mais raso, face planície litorânea seguida por nova regressão.

Palavras-Chave: Faixa Paraguai; Mapeamento geológico; Unidades litoestratigráficas; Ambiente deposicional.

ABSTRACT - Geological mapping conducted in the eastern portion of the Paraguai Belt, in Nova Xavantina region, Mato Grosso state, Brazil, allowed the individualization of four informal lithostratigraphic units: (i) Bacuri, composed of iron formations and banded metacherts; (ii) Antártico defined by lithotypes arranged in cycles of heterolithic facies of quartz phyllite, marble, calciferous phyllite, metarkose, metaconglomerate, metasiltite and metagreywacke, exhibiting gradational bedding, associated with plane-parallel, crushed and convoluted laminations, as well as stratifications in lenses, which reflect a deposition controlled by mixed processes (waves and tides); (iii) Touro Branco, represented by metarenite and quartzite with great compositional maturity, planar and cross-tabular crossstratifications of low angle, besides wavy and erosion marks; (iv) Fazenda Cachoeirinha, marked by homogeneous laminated phyllites. The information collected suggests that these rocks were deposited in a transitional marine environment, formed in a transgressive mega cycle that ends by a progression in a distal marine environment, which towards the top and laterally becomes shallower, facing the coastal plain followed by new regression.

Keywords: Paraguay Belt; Geological mapping; Litho-stratigraphics units; Depositional environment.

\section{INTRODUÇÃO}

A formação da parte ocidental do seja por dobras e empurrões ao longo das antigas supercontinente Gondwana ocorreu através de margens continentais durante processos uma longa sucessão de eventos colisionais chamados coletivamente de evento Brasiliano ou Pan-Africano (Brito Neves et al. 1999; Meert 2003). Segundo Valeriano et al. (2008) estes cinturões orogênicos acomodaram a maior parte da convergência litosférica, seja pela subducção da litosfera oceânica nas fases pré-colisionais, colisionais. Neste ínterim é reconhecida a província Tocantins marcada por três cinturões orogênicos: Araguaia, Brasília e Paraguai, situados entre os blocos continentais Amazônico, São Francisco-Congo e Paranapanema (Figura 1, Almeida et al. 1981; Brito Neves et al. 2000; Valeriano et al. 2008). 
A Faixa Paraguai representa a faixa orogênica mais ocidental da Província Tocantins localizado na porção sudeste do Cráton Amazônico, compreende uma espessa sucessão de margem passiva composta por rochas sedimentares siliciclásticas, carbonáticas, e em menor proporção vulcânicas e vulcano-sedimentares. Estas rochas foram deformadas $\mathrm{e}$ metamorfizadas durante a Orogenia Brasiliana. Durante a orogenia a rochas dos diversos ambientes deposicionais foram deformados por intensa tectônica tangencial, marcada por falhas de empurrão e dobras assimétricas em direção ao Cráton Amazônico e também a zonas de cisalhamento transversais, algumas posteriores aos empurrões, outras contemporâneas. Em função deste quadro tectônico identifica-se uma compartimentação vertical, marcada pela imbricação de domínios litotectônicos e uma compartimentação longitudinal devida aos truncamentos causados pelas zonas de cisalhamento transversais, o que dificulta a modelagem geológica desses orógeno.
A geologia das rochas metamórficas da Faixa Paraguai é relativamente bem conhecida nas regiões da Baixada Cuiabana no estado de Mato Grosso e na Depressão do Rio Miranda, Mato Grosso do Sul. Outras ocorrências são muito pouco estudadas, como na da região de Nova Xavantina, situado no médio rio Araguaia, leste do estado do Mato Grosso. Os dados existentes sobre esta região abrangem estudos geológicos regionais (Drago et al., 1981; Lacerda Filho et al., 2004), estudos geofísicos regionais (Silva, 2007), e o distrito aurífero de Nova Xavantina (Pinho, 1990; Martinelli, 1998; Silva, 2007; Socio, 2008; Sousa, 2010; Callori \& Maronesi, 2011). Percebe-se uma carência de mapeamentos geológicos sistemáticos implicando em incertezas sobre correlações estratigráficas e dificultando modelamentos estruturais e tectônicos. O presente trabalho tem por objetivo apresentar os resultados de mapeamento geológico na escala de 1:50.000 de uma área de aproximadamente $500 \mathrm{~km}^{2}$ situada a sudoeste da cidade de Nova Xavantina.

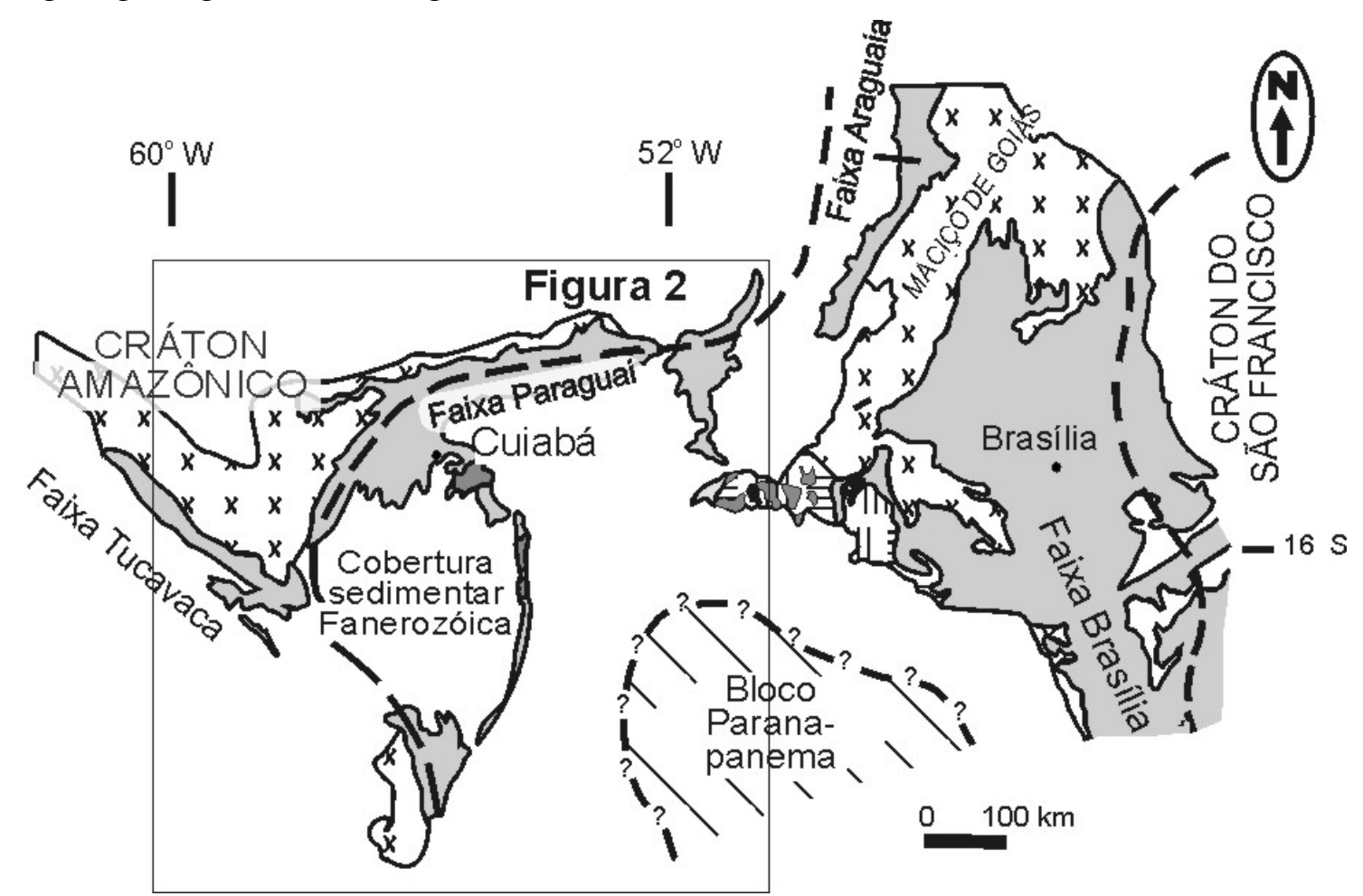

Figura 1. Mapa esquemático da Província Tocantins segundo Pimentel \& Fuck (1992). A área delimitada pelo retângulo é representada na Figura 2.

\section{CONTEXTO GEOLÓGICO REGIONAL}

A área estudada situa-se na Província Tocantins que é um dos principais elementos que compõe a parte ocidental do Supercontinente Gondwana (Brito Neves \& Cordani, 1991). A Província Tocantins reúne três faixas móveis Paraguai, Brasília e Araguaia, as quais resultaram da colisão dos crátons Amazônico, São Francisco-Congo e Paranapanema (Almeida 1984; Pimentel \& Fuck, 1992; Mantovani \& Brito Neves 2005).

A Faixa Paraguai, ocupa a porção ocidental da Província Tocantins, possui aproximadamente 
$1000 \mathrm{~km}$ de extensão com forma de arco com concavidade voltada para sudeste do Cráton Amazônico (Almeida, 1984). Seus principais limites estão cobertos pelas rochas sedimentares das bacias do Paraná, Pantanal e Parecis. A Faixa Paraguai se divide em dois segmentos. O segmento sul aflora nas regiões da Serra da Bodoquena e no vale do rio Miranda no estado do Mato Grosso do Sul. O segmento norte aflora nas regiões da Província Serrana, Baixada Cuiabana e Vale do Araguaia no estado de Mato Grosso. Um ramo NW-SE da faixa interpretado como aulacogeno, ocorre de Corumbá ao interior da Bolívia, onde recebe a denominação de Cinturão Tucavaca (Figura 2, Alvarenga et al., 2000).

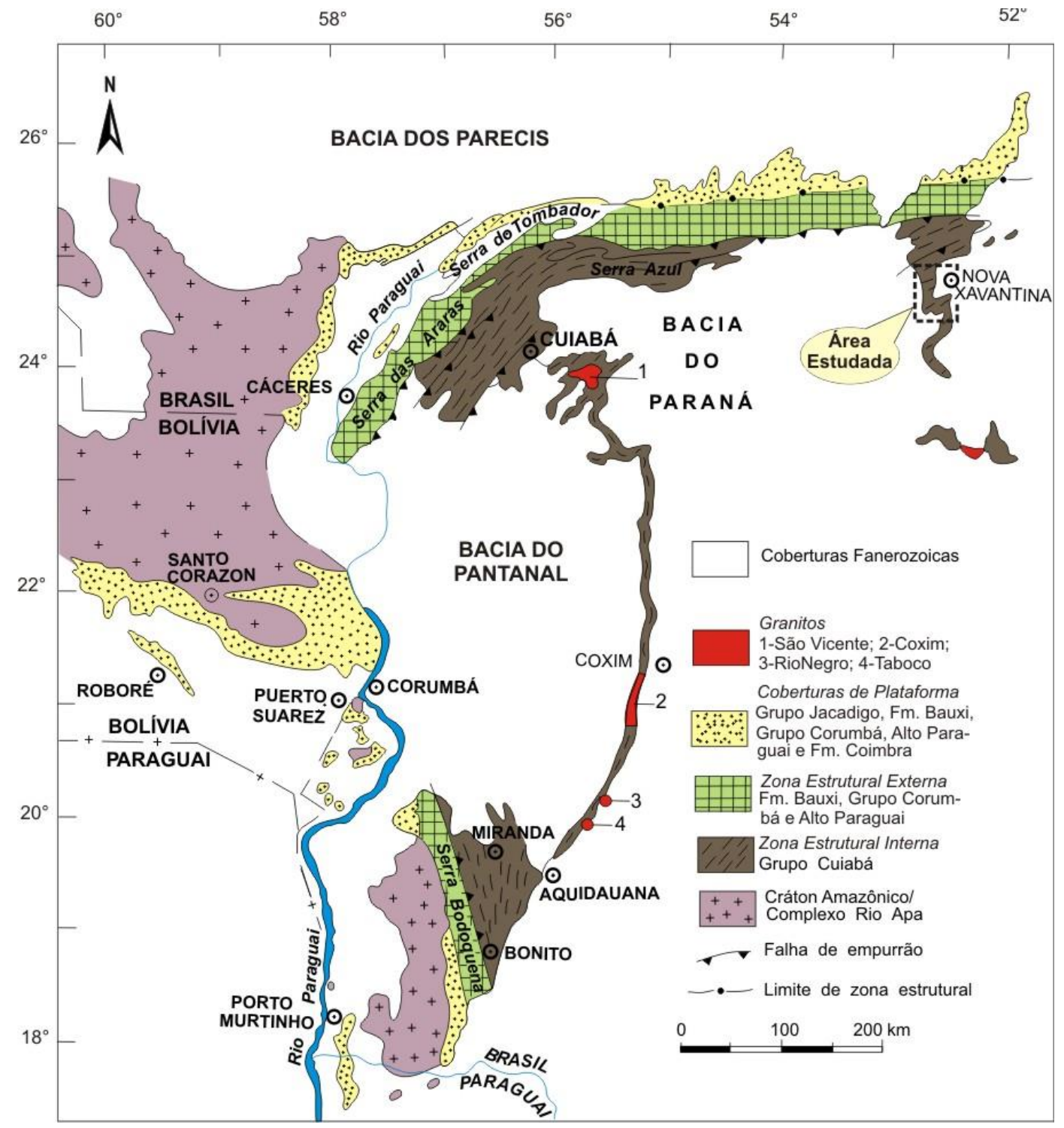

Figura 2. Mapa esquemático da Faixa Paraguai (modificado de Almeida 1984).

Uma zonação tectônica da Faixa Paraguai foi proposta por Almeida (1984) e redefinida por Alvarenga \& Trompette (1993) com a subdivisão em três domínios: Cobertura Cratônica, Domínio Externo, e Domínio Interno (Figura 2). A área estudada situa-se no domínio interno composto por rochas depositadas em regiões distais do cráton Amazônico. Alvarenga \& Trompette (1992) admitem uma evolução lateral da sedimentação do Grupo Cuiabá e de seus equivalentes cratônicos (formações Bauxi e Puga) compatível com o desenvolvimento de margem passiva situada na borda oeste de um oceano brasiliano, ou da acumulação na borda de aulacógeno ou rifte continental.

O domínio interno é representado pelas rochas metassedimentares do Grupo Cuiabá e corpos graníticos $\sin$ a pós-orogênicos do tipo São Vicente. Localmente, como nas regiões de Nova Xavantina e Bonito, ocorrem rochas metavulcânicas e metavulcanoclásticas atribuídas à remanescente de fundo oceânico (Pinho, 1990; Martinelli, 1998; Lacerda Filho et al., 2006).

A litoestratigrafia do Grupo Cuiabá na região 
da Baixada Cuiabana foi revisada por Tokashiki \& Saes (2008) que propuseram o emprego de unidades informais que resgatam denominações clássicas na literatura geológica da Faixa Paraguai a partir do refinamento dos trabalhos de Luz et al. (1980), Alvarenga (1988, 1990), Alvarenga e Saes (1992). Na concepção de Tokashiki \& Saes (2008) a Formação Campina de Pedra de Freitas (2003) marca a base do Grupo Cuiabá na Baixada Cuiabana. Esta unidade é composta por filitos carbonosos, filitos, quartzitos e dolomitos, além de mármores calcíticos e metagrauvacas feldspáticas, depositados em ambiente lacustre rico em carbono orgânico. Sobre estas rochas, Tokashiki \& Saes (2008) reconhecem a Formação Acorizal, que corresponde a Sequência Média Turbidítica Glácio-marinha de Alvarenga (1988) e às subunidades 3, 4, e 5 de Luz et al. (1980). Esta formação é constituída por metaconglomerados, filitos, metatilitos, metarcóseos e quartzitos de origem glácio-marinha. Acima da Formação Acorizal ocorre a Formação Coxipó composta por filitos conglomeráticos, metarenitos, quartzitos, mármores e metadiamictitos petromíticos, parcialmente correlacionada à Formação Marzagão de Almeida (1964), e às subunidades 6 e 7 de Luz et al. (1980), e a Fácies Proximal da Unidade Média Turbidítica Glácio-marinha de Alvarenga (1988).

A idade das rochas do Grupo Cuiabá ainda permanece em debate, no entanto estudos de proveniência de sedimentos conduzidos por Babinski et al. (2018) mostram que a fonte predominante das rochas do grupo são rochas de idade é Ectasiana ( 1230 Ma). A idade máxima de deposição foi determinada a partir de dois grãos de zircão da Formação Coxipó, no topo da sequência, idades de $652 \pm 5$ Ma e $655 \pm 8$ Ma.

Na região do médio Araguaia Lacerda Filho et al. (2004) citam filitos e metarenitos pertencentes ao Grupo Cuiabá. Menezes \& Silva (2008) descrevem ocorrências de calcário associadas ao Grupo Cuiabá, no município de Nova Xavantina. Descrevem mármores calcíticos a dolomíticos, calcarenitos, calcissiltitos e metamargas argilosas, bastantes recristalizados, com laminações, intraclastos, oóides, além de níveis brechados e silicificados. Na mesma região, aflora a Sequência Metavulcano-sedimentar Nova Xavantina que foi estudada por Pinho (1990), Martinelli (1998), Martinelli e Batista (2003), Martinelli (2007), Silva (2007), Socio
(2008) e Callori \& Maronesi (2011). Esses autores descrevem a presença de uma associação de rochas metavulcânicas, metavulcanoclásticas e metassedimentares, em cuja base ocorrem rochas metavulcânicas, tais como metabasalto, metatufo, metandesito e metalapilitufo. Sobre estas ocorrem rochas silicáticas, carbonáticas e ferríferas. No topo da sequência ocorrem rochas psamíticas e pelíticas. Pinho (1990) admite que sequência seja originada em fase embrionária de abertura oceânica em ambiente marinho, possivelmente do tipo back-arc. Já Silva (2007) a partir de dados litogeoquímicos das rochas vulcânicas concluiu que o vulcanismo ocorreu em um rift continental do Neoproterozoico.

As datações das rochas da Sequência Metavulcano-sedimentar Nova Xavantina ainda são escassas. Dantas et al. (2007) apresentou datação U-Pb SHRIMP de um tufo ácido. Descrevem a presença de várias populações de zircão com idades de 2,0, 1,4 1,2 Ga, que são interpretadas como grãos herdados derivados de fontes continentais. Consideram que a idade de $822 \pm 9$ Ma em três grãos de zircão como a melhor estimativa para a idade de cristalização dessa rocha. Geraldes et al. (2018) efetuou análises Ar-Ar em rochas da Sequência Metavulcanossedimentar Nova Xavantina. Tendo sido obtido idades platô ${ }^{40} \mathrm{Ar}$ $/{ }^{30} \mathrm{Ar}$ entre 541 e $531 \pm 0,6 \mathrm{Ma}$ que, segundo os autores, definem o período de resfriamento do evento metamórfico regional relacionado à colisão entre o Cráton Amazônico e o bloco Paranapanema.

As regiões mais distais da Faixa Paraguai são marcadas por magmatismo granítico representado por sete corpos intrusivos. Godoy et al. (2007, 2010) separam este magmatismo em dois grupos de acordo com suas assinaturas geoquímicas e idades. Os corpos situados no estado do Mato Grosso do Sul que afloram na forma de pequenas intrusões alongadas segundo NE-SW, representadas pelos granitos Taboco, Rio Negro, Coxim e Sonora, com características geoquímicas de granitos do tipo I, cálcio-alcalinos de alto potássio peraluminosos, e idades em torno de 540 MA. Os situados a norte no estado de Mato Grosso, são representados pelos granitos São Vicente, Araguaiana e Lajinha com características geoquímicas de granitos do tipo A, cálcioalcalinos de alto potássio a shoshonítico, intraplaca, e com média de idades de $510 \mathrm{Ma}$. 


\section{GEOLOGIA DA REGIÃO DE NOVA XAVANTINA}

No presente trabalho foi priorizado o tares a leste. Na área estudada verificou-se a exislevantamento geológico do domínio interno da Faixa Paraguai de uma área de aproximadamente $490 \mathrm{~km}^{2}$ situada a $\mathrm{SW}$ da cidade de Nova Xavantina. Nesta região as rochas da Faixa Paraguai afloram em uma faixa junto à orla da Bacia do Paraná, a oeste, e das coberturas sedimentência de rochas metassedimentares reunidas em três unidades informais Bacuri, Antártico e Touro Branco, cuja distribuição na área de estudo pode ser observada na Figura 3. As relações estratigráficas e sedimentologicas são caracterizadas no perfil geológico e na seção colunar (Figura 4).

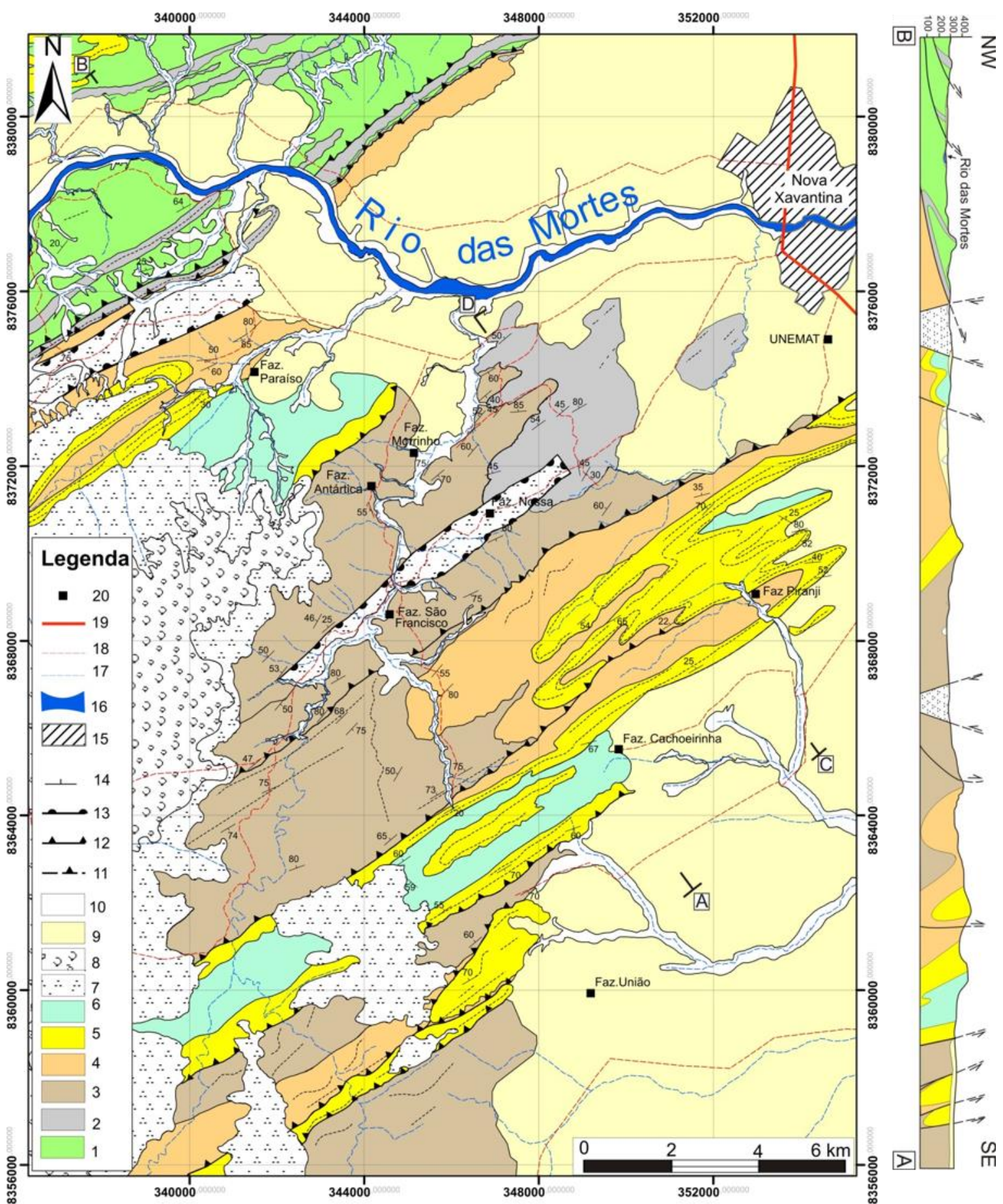

Figura 3. Mapa e seção geológicos da região de Nova Xavantina. Legenda 1. Sequência Metavulcanosedimentar Nova Xavantina - Rochas metavulcânicas e metavulcanoclásticas; 2. Unidade Bacuri - Metacherts e jaspilitos; 3. Unidade Antártico - Filitos, metarenitos, metasiltitos, metarcóseos, metaconglomerados e metagrauvacas; 4. Unidade Antártico filitos e metasititos; 5. Unidade Touro Branco - Metarenito e quartzitos; 6. Unidade Fazenda Cachoeirinha - Filitos; 7. Grupo Rio Ivaí - Conglomerados monomíticos; 8. Formação Furnas- Arenitos mal selecionados; 9. Cobertura detritico-lateriticas; 10. Aluviões; 11. Falha reversa ou de empurrão encoberta; 12. Falha reversa ou de empurrão; 13. Falha normal; 14. Atitude de Acamamento; 15. Area Urbana; 16. Rio; 17. Corrego; 18. Estrada vicinal; 19. Rodovia; 20. Sítio ou Fazenda.

São Paulo, UNESP, Geociências, v. 38, n. 4, p. 837 - 851, 2019 


\section{Litologias Estruturas Sedimentares}
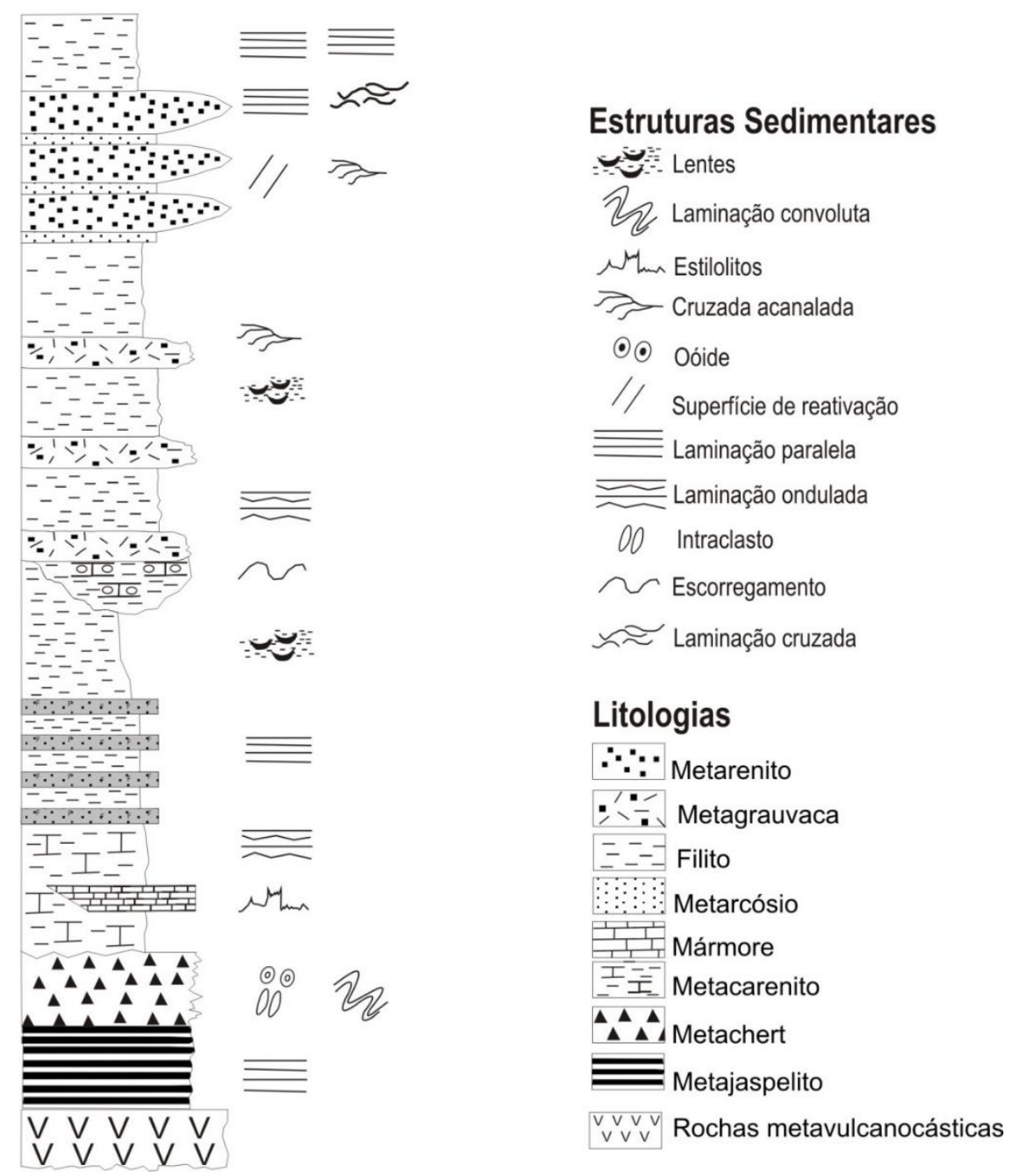

Figura 4. Coluna litoestratigráfica da região de Nova Xavantina.

\section{Litoestratigrafia}

A partir da realização dos perfis geológicos transversais foi possível estabelecer o empilhamento estratigráfico das rochas estudadas e reuni-las, da base para o topo, nas unidades informais: Bacuri, Antártico e Touro Branco, cujas características serão a seguir descritas.

\section{Unidade Bacuri}

A Unidade Bacuri é constituída por associação metassedimentar de natureza química com composição variando de silicática a ferrífera. Seu principal litotipo é metachert, que aflora como blocos e lajedos expostos no topo e nas encostas de morros e morrotes. Estas rochas ocorrem na porção norte da área junto ao rio das Mortes e também a nordeste, nas proximidades da Fazenda Bacuri, onde a associação pode ser caracterizada com maior detalhe. Outras ocorrências isoladas são observadas em direção à área urbana de Nova Xavantina, onde ocorrem parcialmente encobertas por crosta laterítica.
O contato inferior da Formação Bacuri com as rochas da Sequência Metavulcano-Sedimentar Nova Xavantina na área estudada pode ser por falhas de empurrão ou por contato brusco. Já o superior ainda não é totalmente compreendido. $\mathrm{Na}$ região da Fazenda Bacuri este limite apresenta-se na forma de uma superfície erosiva com filito ou na forma de contato transicional com metarenito e metamargas da Unidade Antártico. Na porção nordeste da área, na região da Fazenda Paraiso, o contato é por falha de empurrão.

O comportamento estratiforme é caracte-rizado em escala mesoscópica por um conjunto litológico de metarcherts que variam entre quartzoso, ferruginoso e oolítico, e metajaspilito, que ocorrem em bandas milimétricas, o que resulta na mudança nas cores de cinza a branca para bandas quartzosas e avermelhada nas bandas ferruginosas (Figura 5A). São observadas feições de micro deformação (falhas e dobras), diaclasamento, e brechas intraclásticas, associadas a camadas ou a um conjunto 

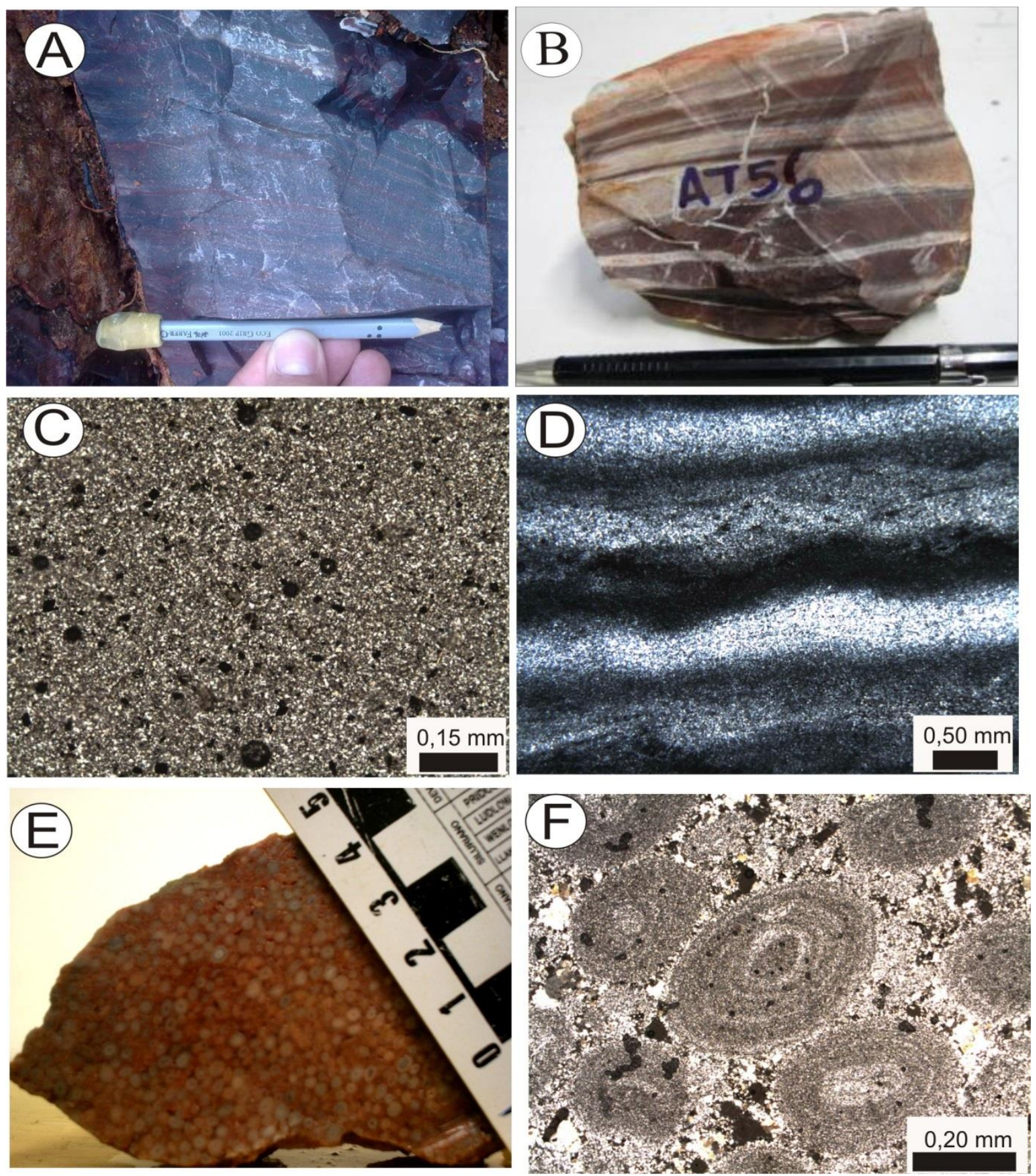

Figura 5. A) Metachert branco, bandado, com níveis milimétricos ferríferos; ocorrem microfraturas e microfalhas ortogonais ao bandamento composicional, algumas preenchidas por material ferruginoso. B) Fotomicrografia do metachert da foto A apresentando o aspecto microgranular do quartzo, em polarizador paralelo. C) Metajaspilito brechado, cimentado por quartzo leitoso. D) Estrutura oolítica em metachert quartzoso da Fazenda Bacuri. Em polarizador paralelo. E) Foto-micrografia de metachert oolítico. Destaca-se a forma ovalada e a textura radial dos oóides e mosaicos definidos pelos cristais de quartzo da matriz. Em polarizador paralelo. F) Fotomicrografia do itabirito, marcado por bandamento composicional, ondulado dado pela alternância de bandas ricas em quartzo microcristalino e hematita. Em polarizador paralelo.

de camadas. O metachert quartzoso é branco a preto, apresentando discreto bandamento alternando entre camadas brancas, cinzas e avermelhadas, às vezes separadas por níveis milimétricos ferríferos (Figura 5B). Em seção delgada a rocha é fina a muito fina com textura granoblástica, constituída por quartzo microgranular poligonal, e em menor proporção mica branca (Figura 5C). O metajaspelito (metachert ferruginoso) ocorre em blocos silicificados, rosa a vermelho, ora maciços, ora brechados, granulação fina a média. A textura é granular com presença de grãos finos de quartzo, às vezes com matriz recristalizada, além de brechação e venulações (Figura 5D). Em lâmina delgada exibe tem estrutura bandada, na qual predomina o quartzo, intraclastos, diminutos cristais de plagioclásio alterado, micropor- 
firoblastos de muscovita, e matriz muito fina composta por óxido de ferro (Figura 5E).

$\mathrm{O}$ metachert oolítico ocorre próximo à Fazenda Bacuri em camadas centimétricas associadas ao metachert quartzoso. É de cor rosa avermelhada e contém oóides ovais, elípticos ou alongados, com diâmetros entre 0,25-0,4 cm, com estrutura concêntrica assimétrica, com núcleo constituído por quartzo microcristalino, por vezes óxido de ferro (Figura 5E). Em menor proporção ocorre uma matriz fina a muito fina constituída por quartzo e minerais opacos está a matriz intergranular de quartzo ajustada aos contatos dos oólitos (Figura 5F).

\section{Unidade Antártico}

As rochas da Unidade Antártico ocorrem na maior parte da área mapeada, mas as principais ocorrências estão expostas ao longo do vale do Ribeirão Antártico, porção central da área, caracterizada por morros de topo suave e vales encaixados. A unidade é composta por metarenitos, metarcósios, metagrauvacas, metassiltitos, filitos e por rochas químicas subordinadas. As camadas estão distribuídas de forma cíclica e acham-se dispostas em fácies heterolíticas, quase sempre por contatos gradacionais, com possível variação lateral de fácies. O contato superior com a Formação Touro Branco é brusco, marcado pelo contato entre as rochas pelíticas da Unidade Antártico com as psamíticas da Unidade Touro Branco.

Os litotipos predominantes da unidade são filitos com intercalações de metarenito, que dão lugar, em direção ao topo a mármore dolomítico associado à metassiltito calcífero. Também ocorrem lentes de metarenito e calcirudito rico em fragmentos de carbonato, que passam gradualmente para metagrauvacas, filitos e metassiltitos micáceos. As estruturas primárias comuns nestas rochas compreendem estratificações e laminações plano-paralelas, onduladas e cruzadas, acamamento gradacional e lenticular, marcas de ressecamento e de escavação (scours), além de feições localizadas, como dobras convolutas e de escorregamento, atribuídas a deformação sindeposicional.

O filito é a rocha mais abundante e ocorre ao longo de toda a seção da formação em associação com os demais litotipos. Na base ocorrem filitos marrom rosado de granulação fina com laminação planar incipiente (Figura 6A). Constituído por filossilicatos (muscovita, sericita e clorita) e quartzo. São observados níveis enriquecidos em óxido de ferro, possivelmente devido a enriquecimento supérgeno. Na porção intermediária, o filito ocorre em arranjos rítmicos associados a metarenitos feldspáticos. Nesta situação o filito é rosa ou verde esbranquiçado, com laminação evidente e micro-lentes interestratificadas. No topo da sucessão, o filito é cinza ou roxo, sem laminação evidente, mas com estratificação gradacional com metarenito e metagrauvaca.

Os metarenitos tem distribuição restrita. Ocorrem interestratificados com os metapelitos. Este litotipo é heterogêneo, pois varia em composição, tamanho de grãos, estruturas primárias. Uma característica comum a estes metarenitos é a má seleção, que evidenciam imaturidade composicional. Na porção intermediária da unidade ocorrem metarenitos com menos de $15 \%$ de matriz e composição arcosiana a subarcosiana (Figura 6B), ao passo que no topo a matriz supera os $15 \%$ e os metarenitos apresentam composição grauvaquiana a quartzo grauvaquiana.

$\mathrm{Na}$ estrada para a Ilha do Coco, a noroeste da área, próximo da Fazenda Olho D’água, aflora uma associação de rochas composta por mármore dolomítico, metassiltito e metarcóseo, gradando para metarcósio. O metarcóseo e o metassiltito são verde esbranquiçados, tem textura polimodal, granulação média a fina, com grãos de quartzo, feldspato e micas, e uma matriz fina de mesma composição com níveis ricos em carbonato. Estas rochas possuem laminações plano-paralelas, onduladas e cruzadas de baixo ângulo e pequeno porte (Figura 6C). Os mármores têm ocorrência restrita e possuem expressivo conteúdo terrígeno, o que permite classificá-los como metamargas. São cinza claro, com laminação plano-paralela e composição dolomítica (Figura 6D). O metarcósio é rosa quando fresco, passando a marrom amarelado, quando alterado (Figura 6E). Apresenta granulação média, sendo constituída por quartzo, feldspato e fragmentos de rochas carbonáticas e ferríferas com matriz fina composta por carbonato, quartzo e mica.

As metagrauvacas são cinza esverdeadas quando frescas, ou marrom alaranjada quando alterada, finas a médias, compostas por clastos de plagioclásio (albita e ortoclásio), quartzo, fragmentos de rocha e micas, angulares com baixo arredondamento (Figura 6G). Os clastos estão envoltos por uma matriz fina a muito fina, constituída por plagioclásio, quartzo, muscovita e clorita, e rara biotita. A principal estrutura associada a estas rochas é estratificação gradacio- 

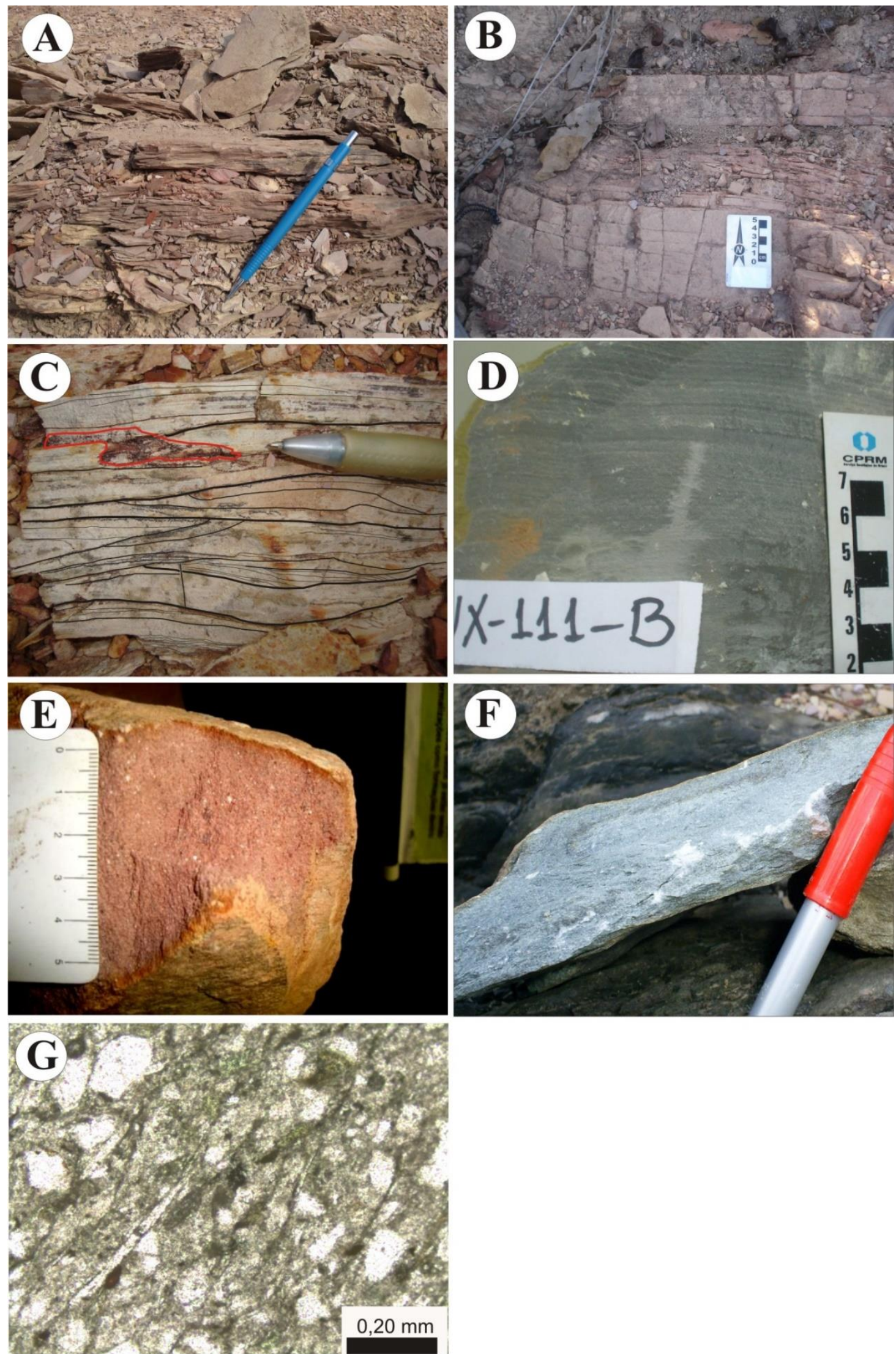

Figura 6. A) Afloramento de filito da Formação Antártico, no qual destaca-se clivagem ardosiana, a qual promove desplacamento. B) Afloramento de metarcóseo rosa, alterado, com gradação normal para metassilito laminado. C) Afloramento de metarcóseo fino, branco, apresentando laminações onduladas e cruzadas. No lado esquerdo superior ocorre concentração de óxido de ferro. D) Amostra de mármore dolomítico cinza laminado. E) Amostra de metarenito feldspático rosa, com quartzo e feldspato. F) Amostra de metagrauvaca verde, com granulação fina a média. G) Fotomicrografia de metagrauvaca fedspática, com textura granolepidoblástica com cristaloclastos de feldspato moderadamente selecionado e arredondado. Apresenta uma matriz fina composta por feldspato potássico, quartzo, clorita, epidoto e muscovita orientada segundo a foliação principal da rocha. Foto obtida em polarizador paralelo. 
cional centimétrica marcada pela variação na granulação, com granodecrescência e espessamento ascendente. Outras estruturas comuns são laminações paralelas onduladas de baixo ângulo e cruzadas acanaladas onde os contatos das camadas frontais (entre topo e base) se comportam de forma tangencial junto aos limites curvilíneos.

Na porção intermediária da unidade Antártico ocorrem corpos métricos a decimétricos lenticulares de metaconglomerados associados a filitos e metagrauvacas. Os metaconglomerados são matriz suportados, cinza esverdeado quando fresco, marrom amarelado quando alterado (Figuras 7A e B), possuem trama inequigranular constituída por fragmentos de calcários (calcarenitos e calcilutitos), metachert, metajaspilito, quartzito, filitos, filito carbonoso, xistos e rochas metavulcânicas, além de quartzo, plagioclásio (albita e ortoclásio), feldspato potássico (Figura C). O tamanho do clastos varia entre grânulo a matacão, os fragmentos maiores são angulares com baixa esfericidade, já os menores são angulosos a moderadamente arredondados. Alguns fragmentos preservam estruturas reliquiares, tais como laminação plano-paralela, em mármores, ou textura de fluxo magmático, em metavulcânicas. Envolvendo os clastos é observada uma matriz heterogênea de granulação fina, constituída por quartzo, feldspato potássico, plagioclásio, mica branca e carbonato, além de clorita, epidoto e biotita em menor proporção. (Figura 7D).

\section{Unidade Touro Branco}

A Unidade Touro Branco é constituída por metarenitos, que sustentam um relevo acidentado formado por cristas alongadas que permitem o traçado da unidade por dezenas de quilômetros. Estratigraficamente posiciona-se acima da associação psamo-pelítica da Unidade Antártico por contato brusco. Em locais menos deformados, é possível observar estruturas sedimentares preservadas, destacando-se marcas onduladas simétricas (flaser) e cruzada de baixo ângulo, acamamentos tabulares a sigmoidais, com superfícies de reativação (Figuras 7E-F).

$\mathrm{O}$ principal litotipo dessa unidade é o metarenito, branco a cinza quando fresco, ou cinza rosado quando alterado, fina a média, com bom grau de seleção dos grãos (Figura 77). É constituída por quartzo, que define uma textura granoblástica, em função da intensidade da deformação pode variar a forma, desde arredondado a subangular com alta esfericidade e bom grau de seleção com contatos pontuais (Figura $8 \mathrm{H}$ ), até alongado, com evidências de deformação interna expressa em extinção ondulante, lamelas de deformação, subgrãos e recristalização, principalmente nas bordas. A foliação dos metarenitos é dada pela orientação dos grãos de quartzo e da matriz metamórfica Além do quartzo é possível observar plagioclásio e fragmentos de rocha principalmente de quartzito, filito, metajaspilitos e metachert.

Outro litotipo comum nesta formação é o quartzito, que apresenta distribuição restrita às zonas de falha. É uma rocha de cor branca a amarelada, com granulação fina a muito fina. Constitui-se essencialmente por quartzo com uma fina matriz composta por quartzo e sericita, e distingui-se do metarenito por não apresentar trama sedimentar preservada. Ao microscópio o quartzo define uma textura poligonal com contatos retangulares. Em outros locais ocorre porfiroclastos de quartzo com intensa extinção ondulante, lamelas de deformação e formação de sub-grãos.

\section{Unidade Fazenda Cachoeirinha}

Esta unidade aflora na porção central e sul da área mapeada, representa o topo da sucessão sedimentar da Faixa Paraguai na área mapeada. Apresenta contato brusco com as rochas da Unidade Touro Branco. Constitui-se essencialmente por filitos, e em menor proporção metassiltitos e quartzitos. Os filitos apresentam coloração arroxeada, granulação fina a muito fina, em algumas porções exibe laminação de escala milimétrica a centimétrica. Em todos os afloramentos exibe clivagem ardosiana definida pelos filossicatos. Microscopicamente apresenta uma textura lepidoblástica, sendo composto basicamente por filossilicatos (mica branca, biotita e clorita) e quartzo.

\section{DISCUSSÃO}

\section{Evolução sedimentar}

O mapeamento geológico em conjunto com as feições sedimentares das rochas, permitiu a individualização de quatro unidades litoestratigráficas informais que podem ser agrupadas em dois sistemas deposicionais.

O sistema inferior é composto por metacherts e itabiritos da Unidade Bacuri. Interpreta-se que essas rochas foram depositadas por ação química, e que o bandamento composicional presente 

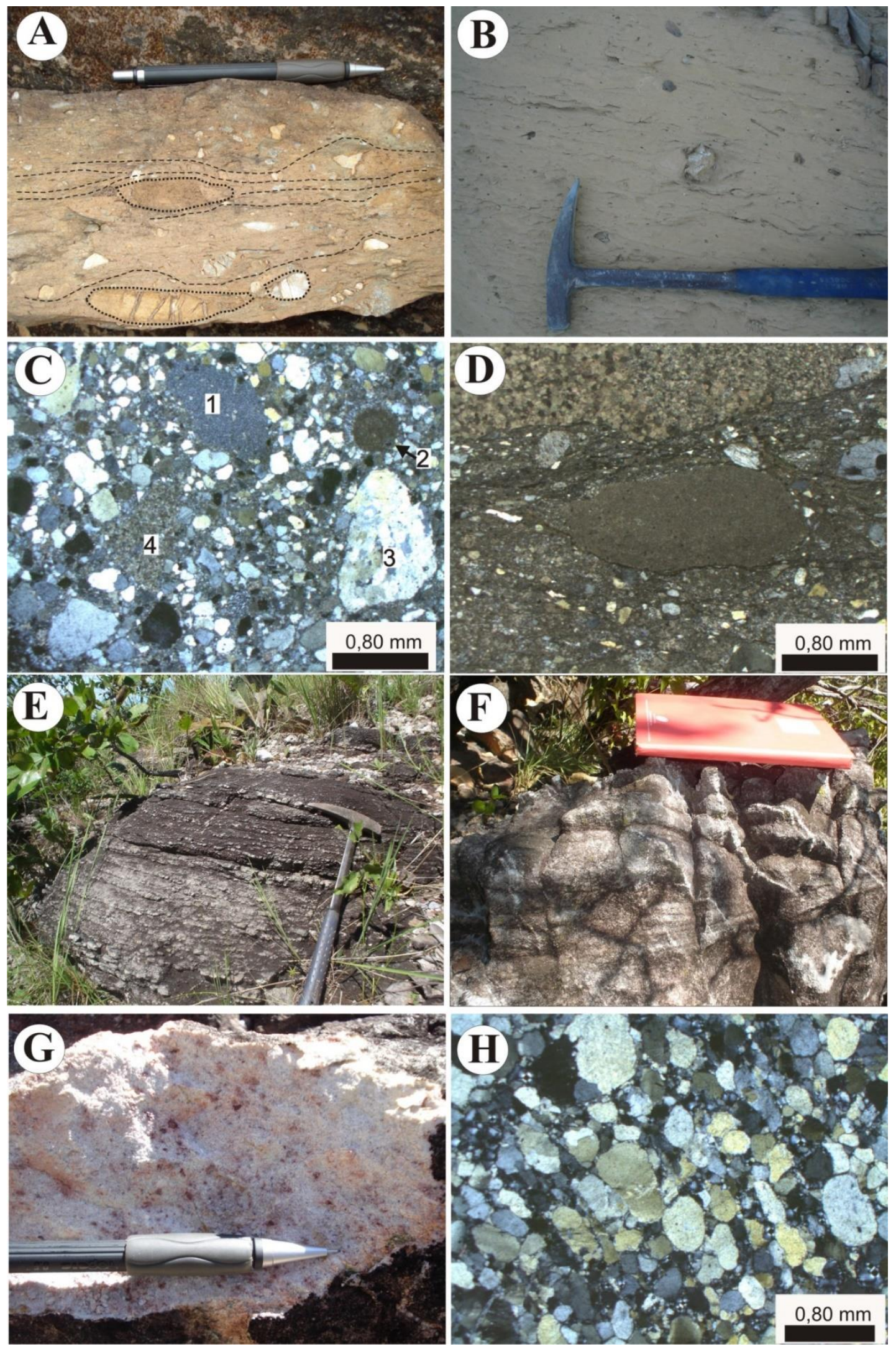

Figura 7. A) Afloramento de metaparaconglomerado constituído por fragmentos líticos alongados e uma matriz fina a média rica em carbonato. Dentre os fragmentos líticos destacam-se: metachert, mármores calcíticos e dolomíticos, quartzitos e filitos, alguns apresentam fraturas e/ou sombra de pressão. B) Afloramento de metaparaconglomerado alterado onde destaca-se a matriz fina de cor marrom amarelado rica em carbonato. As cavidades observadas são originadas a partir da dissolução do carbonato. C) Fotomicrografia do metaparaconglomerado, onde podem ser observados vários fragmentos de rochas e minerais, como por exemplo: metachert (1), carbonato, com borda de quartzo microcristalino (2), quartzito (3), metacalcário, com foliação incipiente (4). D) Fotomicrografia do metaparaconglomerado, onde destaca-se um litoclasto de carbonato fino (micrito); a matriz tem granulação fina, predominando quartzo e carbonato. Na porção superior ocorre um nível rico em carbonato micro granular. 
nessa rocha originou-se a partir da precipitação do ferro e da sílica na granulação fina a muito fina. Segundo Tucker (1991) a deposição de cherts pode ocorrer de maneira inorgânica ou orgânica. Quando depositada de maneira inorgânica originam-se da precipitação de sílica coloidal em ambientes de fundo do mar. Nesta situação os cherts estão associados emanações vulcânicas e/ou fluxos vulcânicos submarinos, junto à pelitos de águas profundas. Outra forma de ocorrência dos cherts independe de eventos vulcânicos, nesta situação são depositados a partir da acumulação de restos de sílica presente nos organismos de diatomáceas, radiolárias ou em espículas de esponja, e são associados a calcários pelágicos, sedimentos siliciclásticos e carbonáticos turbidíticos. No caso de Nova Xavantina, interpretação sobre o ambiente deposicional revela que os tipos puramente químicos teriam se formados em águas calmas e profundas afastadas da borda continental, onde a taxa de fornecimento de sedimentos terrígenos é baixa, nas porções distais da planície abissal. As ocorrências de rochas vulcânicas em áreas adjacentes à estudada, pode comprovar as evidências de deformação localizadas, tais como: microfalhas, dobras e brechas, indicam a existência de movimentação durante a deposição (extra- ou intraformacional). Esta movimentação possivelmente foi associada a erupções vulcânicas ou a fumarolas, que serviram de fonte para as soluções coloidais que originaram os cherts e as formações ferríferas. Assim, é possível que as rochas da Unidade Bacuri estejam relacionadas ao vulcanismo, e como as rochas descritas na unidade química da Sequência Metavulcanossedimentar Nova Xavantina (Pinho 1990; Martinelli 1998).

O Sistema Superior agrupa das unidades Antártico, Touro Branco e Fazenda Cachoeirinha. A unidade basal é marcada por rochas metapelíticas (filitos e metassiltitos) com intercalações subordinadas de metarenitos quartzosos e feldspáticos (metarcósios e metagrauvacas), além de mármores e metaparaconglomerados. As diversidades de litologias e estruturas sedimentares refletem uma deposição controlada por processos mistos, provavelmente influenciados pelo relevo, morfologia do substrato bacinal e proximidade das áreas fonte. As rochas pelíticas apresentam comumente laminação plano-paralelo e discreto acamamento gradacional, partindo de uma rocha na fração areia fina para uma fração argila. A predominância de sedimentos finos permite inferir uma deposição pelágica ou hemi-pelágica em ambiente marinho. Um aparente espessamento das camadas em direção ao sul da área foi observado, admitindo-se pela escassez de areias, como sendo porções mais profundas da bacia marinha.

Na porção intermediária da Unidade Antártico os pelitos estão associados a mármores calcíticos laminados e metamargas dolomíticas de natureza clasto-química. Isto permite considerar que a bacia apresentava condições físico-químicas propícias a precipitação de carbonato. Sendo os principais agentes, a profundidade e a temperatura da água.

$\mathrm{Na}$ parte superior da Unidade Antártico as rochas pelíticas apresentam estruturas como: estratificações lenticulares, onduladas e cruzadas, que evidenciam uma zona deposição influenciada por fluxos superficiais sujeitos a flutuações periódicas do nível da água. Esta flutuação favorece a alternância da energia da corrente e/ou fluxo, sendo característico nas estruturas em lâminas (linses), onde no momento de maior velocidade do fluxo atuou o processo de tração onde os sedimentos são carreados, logo, no período de baixa energia, o material é sedimentando na forma lâminas e lentes. Já as marcas de ressecamento são atribuídas à exposição ou subexposição da camada a atmosfera, provocada então na variação no nível da água, provavelmente por ação de correntes de marés e/ou ondas.

As rochas arenosas e conglomeráticas da Formação Antártico estão distribuídas ao longo de todo o perfil. Predomina metarenito feldspático, além de metagrauvacas, metarcósios e metaparaconglomerado, que comumente são imaturos com fragmentos de quartzo, além de feldspato e fragmentos de em menor quantidade. Apresentam geometria variável de tabular a sigmóidal, com acamamento gradacional. A presença de feldspato, que em alguns casos é mais abundante que o quartzo, de fragmentos de rochas vulcânicas, mármores e filitos permite afirmar que a área fonte dessas rochas era próxima, o suficiente para não alterar esses fragmentos que são muito susceptíveis a alteração. Esta constatação somada a presença de laminações convolutas, falhas e brechas intrabacinais sugerem que a formação desses fluxos se deu pelo menos em parte a em ambiente 
marinho sob influência tectônica, que soergueram e expuseram a erosão às rochas sedimentares químicas, vulcânicas e vulcanoclásticas anteriormente depositadas. Dessa forma, interpreta-se que essas rochas foram depositadas em um ambiente marinho sobre a ação de correntes de massas gravitacionais e/ou turbidítica, a partir de relevo estabelecido por processo tectônico.

As unidades Formação Touro Branco e Fazenda Cachoeirinha representam o topo da sucessão superior. $\mathrm{Na}$ unidade Touro Branco predomina metarenitos quartzosos com elevada maturidade textural, associados a marcas onduladas simétricas, estratificações cruzadas de baixo ângulo e médio porte, além de acamamentos tabulares a sigmoidais, com superfícies de reativação, mostrando no topo de cada ciclo finas camadas de pelitos quartzosos, que são provenientes da decantação do material em suspensão durante a paralisação da corrente que depois foram sobrepostas por novas camadas de fluxos erosivos. Interpreta-se que as rochas da Formação Touro Branco foram depositadas em uma plataforma marinha rasa, em fácies litorânea sob influência de ondas e secundariamente de marés. Já unidade Fazenda Cachoeirinha com rochas pelíticas com laminação plano paralela representam uma inserção marinha nessa plataforma rasa.

\section{CORRELAÇÕES}

A priori, as possíveis correlações litológicas e estratigráficas dentro do domínio interno da Faixa Paraguai ainda são dificultadas pela carência de dados com descrições detalhadas, onde o arcabouço estratigráfico é geralmente descrito em escala regional. Alvarenga \& Trompette (1992) propuseram que as rochas da Faixa Paraguai foram depositadas em uma margem passiva com influência glacial ao lado de uma bacia marinha relativamente profunda, com aporte e sedimentação vindos do continente através de leques submarinos alongados de noroeste para sudeste, formando os depósitos do tipo fluxos gravitacionais.

$\mathrm{Na}$ área mapeada na região de Nova Xavantina, a deposição dos sedimentos químicos (cherts e jaspilitos) foi em águas calmas e profundas afastadas ou restritas da planície abissal, ou nas porções distais da plataforma continental, onde a taxa de fornecimento de sedimentos terrígenos é baixa. As rochas ferríferas bandadas (BIFs) da Faixa Paraguai são registros geológicos de grandes discussões, principalmente na caracterização cronoestratigráfica e paleoambiental em eventos no Neoproterozoico. Na Sequência Metavulcanossedimentar Nova Xavantina também são descritas rochas ferríferas metamorfisadas constituída por formações ferríferas bandadas, metachert ferruginosos, filitos carbonosos e metachert quartzoso no topo. Assim, é natural que as rochas da Unidade Bacuri estejam relacionadas em parte com a unidade química da Sequência Metavulcanossedimentar Nova Xavantina (Pinho 1990; Martinelli 1998).

A Unidade Antártico apresenta rochas arenopelíticas de ciclos granodecrescentes sujeitos a fluxos de detritos de densidade relativa, típicas de áreas localizadas em sopés da plataforma continental, nas porções mais distais do mar, o que remete uma origem hemi-pelágica. Estas rochas podem ser correlacionadas a Sequência Média Turbidítica Glácio-marinha (fácies intermediária e distal) de Alvarenga (1988) e as subunidades 3 e 4 de Luz et al. (1980) ou ainda a Formação Acorizal de Tokashiki \& Saes (2008). Estes autores consideram que essas rochas foram depositadas na base em ambiente marinho com mostra deposição controlada pela progradação de deltas, e no topo, uma origem marinha com ação glacial, e estas ocorrências são consideradas depósitos da fase de expansão, sin-rifte da bacia. Já as unidades Touro Branco e Fazenda Cachoeirinha não foram descritas nas ocorrências da Faixa Paraguai na Baixada Cuiabana.

\section{CONCLUSÕES}

O mapeamento geológico realizado na região de Nova Xavantina que teve como foco as rochas metassedimentares do Domínio Interno da Faixa Paraguai, permitiu a subdivisão em quatro unidades lito-estratigráficas. A sucessão superior possui duas unidades lito-estratigráficas, as formações Antártico e Touro Branco, e agrupado no mesmo sistema deposicional.

A Formação Antártico é predominante, com extensa distribuição espacial arranjada em três ciclos de litofácies heterolíticas. A principal gradação dos ciclos verticais é a granulação decrescente para o topo, e as estruturas sedimentares são variadas, entre fluxos calmos, 
oscilatórios a turbulentos, que imprime um caráter misto para a de distribuição e processos sedimentares, o que evidenciam uma zona deposicional influenciada por fluxos superficiais, sujeito a flutuações periódicas do nível estático do mar (marés e ondas). A Formação Touro Branco com seus metarenitos quartzosos têm menor expressão entre as unidades mapeadas e também mostra padrão de granodecrescência entre areias e pelitos secundariamente. As camadas com estruturas cruzadas, plano paralelas, flaser, e marca de reativação, denuncia a migração lateral um registro de acumulações de areias intensamente retrabalhadas por ondas, considerado um registro deposicional originado principalmente por retrabalhamento de sedimentos pré-existentes na bacia em uma porção proximal à margem continental, provavelmente, a primeira evidência para identificação de um ambiente sub-litorâneo.

Agrupadas no mesmo sistema, se pode afirmar o contato transicional em ambiente marinho entre as formações Antártico e Touro Branco, sendo possível inferir micro-ambiente de interação, entre frentes de microdeltaicas progradantes e plataforma interligada às porções distais, influenciada por ações de fluxos de marés e ondas. $\mathrm{O}$ sistema deposicional possivelmente tem natureza em trato transgressivo retrogradante nas porções distais, e nas porções proximais, fase de progradação da plataforma continental, afirmação confirmada pela frequente presença de camadas de lentes e sigmóides de metarenito.

\section{AGRADECIMENTOS}

Os autores agradecem a CAPES pelo suporte financeiro ao desenvolvimento da pesquisa. Ao Programa de pós-graduação em Geociências da FAGEO/UFMT. A primeira autora agradece a CAPES pela concessão de bolsa de mestrado.

\section{REFERÊNCIAS}

ALMEIDA, F.F.M. de. Geologia do centro-oeste matogrossense. Boletim da Divisão de Geologia e Mineração - DNPM/DGM, v. 2158, p. 1-137, 1964.

ALMEIDA, F.F.M. Província Tocantins-setor sudoeste. In ALMEIDA, F.F.M. \& HASUI, Y. O (Coordenadores) PréCambriano do Brasil. São Paulo: Ed. Edgard Blücher, p. 265$281,1984$.

ALMEIDA, F. F. M.; HASUI, Y.; BRITO NEVES, B. B.; FUCK, R. A. Brazilian structural provinces: an introduction. EarthScience Reviews, v. 17, p. 1-29. 1981.

ALVARENGA, C.J.S. Turbiditos e a glaciação do final do Proterozóico Superior no Cinturão Paraguai, Mato Grosso, Revista Brasileira de Geociências, v. 18, n. 3, p. 323-327, 1988.

ALVARENGA, C.J.S. 1990. Phénomènes Sèdimentaires, Structuraux et Circulation de Fluides Dèveloppés à la Transition Chaîne-Craton: Exemple de la Chaîne Paraguai d'âge proterozoique supérieur, Mato Grosso, Brésil. Marseille, 1990, 177p. Tese (Doct. Sci.) - Univ. Aix-Marseille III.

ALVARENGA, C.J.S. \& TROMPETTE, R. Glacially influenced in the Later Proterozoic of the Paraguay belt (Mato Grosso, Brazil). Paleogeography, Paleoclimatology, Paleoecology, v. 92, p. 85-105, 1992.

ALVARENGA, C.J.S. \& SAES, G.S. Estratigrafia e sedimentologia do Proterozóico Médio e Superior da região sudeste do Cráton Amazônico. Revista Brasileira de Geociências, v.22, n.4, p. 493-499, 1992.

ALVARENGA, C.J.S. \& TROMPETTE, R. Evolução Tectônica Brasiliana da Faixa Paraguai: a estruturação da região de Cuiabá. Revista Brasileira de Geociências, v. 23, n.1, p.18-30, 1993.

ALVARENGA, C. J. S.; MOURA, C. A. V.; GORAYEB, P. S. S. \& ABREU, F. A. M. Paraguay and Araguaia Belts. In: Cordani, U.G.; Milani, E.J.; Thomaz Filho, A. \& Campos, D. A. (Coordenadores). Tectonic Evolution of South America. Rio de Janeiro: 31st International Geological Congress, , p. 183$193,2000$.

BABINSKI, M., MCGEEA, B., TOKASHIKI, C.C, TASSINARI, C.C.G., SAES, G. S., PINHO, F.E.C. Comparing two arms of an orogenic belt during Gondwana amalgamation: Age and provenance of the Cuiabá Group, northern Paraguay
Belt, Brazil. Journal of South American Earth Sciences v. 85, p. 6-42, 2018.

BRITO NEVES, B.B. \& CORDANI, U.G. Tectonic evolution of South America during the Late Proterozoic. Precambrian Research, v. 53, p. 23-40, 1991.

BRITO NEVES, B. B., CAMPOS NETO, M. C.; FUCK, R. A From Rodinia to Western Gondwana: na approach to the Brasiliano-Pan African Cycle and orogenic collage. Episodes, v. 22, p. 155-166, 1999.

BRITO NEVES, B. B.; ALMEIDA, F. F. M.; CARNEIRO,C. D. R. The origin and evolution of the South American Platform. Earth-Science Reviews, v. 50, p. 77-111, 2000.

CALLORI, D. \& MARONESI, M.G. Mapeamento Geológico em Escala de Detalhe do Vale do Córrego Santo Antônio, Município de Nova Xavantina, Leste do Estado de Mato Grosso. Cuiabá, 2011. 89p. Trabalho de Conclusão de Curso (Graduação em Geologia) - Faculdade de Geociências, Universidade Federal de Mato Grosso.

DANTAS, E.L., ARMSTRONG, R., PIMENTEL, M.M., FUCK, R.A., MARTINELLI, C.D., SILVA, M.F., LAUX, J.H., 2007. 800 Ma rifting in the Paraguay Belt, central Brazil: U-Pb SHRIMP age determination, Rodinia break-up and implications for a connection with Avalonian peri-Gondwana terranes. In: Geological Society of America Annual Meeting, 2007, Denver. Abstracts...Denver, 2007.

DRAGO, V.A., PINTO, A.C., MONTALVÃO, R.M.G. de, SANTOS, R.O.B., SIMÕES, M.A., OLIVEIRA, F.C., BEZERRA, P.E.L., PRADO, P., FERNANDES, C.A.C., TASSINARI, C.C.G. Geologia-Projeto Radambrasil: Levantamento dos Recursos Naturais, Folha SD. 22-Goiás. Rio de Janeiro: MME/SG (ed.), 273 p., 1981.

FREITAS, E.S. Estratigrafia e tectônica do Grupo Cuiabá no flanco NW da Antiforme do Bento Gomes, Poconé, MT. Cuiabá, 2003. 78p. Trabalho de Conclusão de Curso (Graduação em Geologia) - Faculdade de Geociências, Universidade Federal de Mato Grosso.

GERALDES, M.C.; SANTOS, A.C.; SANTOS, W.H.; TASSINARI, C. ${ }^{40} \mathrm{Ar} /{ }^{39} \mathrm{Ar}$ Cooling Ages of the Paraguay Belt in the Nova Xavantina Region (MT): Tectonic Implications for Western Gondwana Collage. Anuário do Instituto de 
Geociências - UFRJ. V. 41, n. 3, p. 351-362, 2018.

GODOY, A.M.; MANZANO, J.C.; RUIZ A.S. \& ARAUJO L.M.B. Os Granitoides Brasilianos Pós-Tectônicos da Faixa de Dobramentos Paraguai MS e MT. Geologia USP: Série Científica, v. 7, n. 1, p. 29-44, 2007.

GODOY, A.M.; PINHO, F. E. C.; MANZANO, J. C.; ARAÚJO, L.M. B.; SILVA, J. A.; FIGUEIREDO, M. Estudos isotópicos das rochas granitóides neoproterozoicas da Faixa de Dobramento Paraguai. Revista Brasileira de Geociências, v. 40, n. 3, p. 380-391, 2010.

LACERDA FILHO, J.V, ABREU FILHO, W., VALENTE, C.R., OLIVEIRA, C.C. \& ALBURQUERQUE, M.C. Geologia e Recursos Minerais do Estado de Mato Grosso. Brasília: Programa Integração, Atualização e Difusão de Dados de Geologia do Brasil. Convênio CPRM/SICME-MS, MME, 235 p., 2004.

LACERDA FILHO, J.W., BRITO, R.S.C., SILVA, M.G., OLIVEIRA, C.C., MORETON, L.C., MARTINS, E.G., LOPES, R.C., LIMA, T.M., LARIZZATTI, J.H. VALENTE C.R. Mato Grosso do Sul. Brasília: Convênio CPRM/SICMEMS, MME, 121 p., 2006.

LUZ, J.S.; OLIVEIRA, A.M.; SOUZA, J.O.; MOTTA, J.F.M.; TANNO, I.C.; CARMO, L.S. \& SOUZA, N.B. Projeto Coxipó. Goiânia: DNPM/CPRM, v. 1, 136p., 1980.

MANTOVANI, M.S.M. \& BRITO NEVES, B.B. The Paranapanema Lithospheric Block: Its Importance for Proterozoic (Rodinia, Gondwana) Supercontinent Theories. Gondwana Research, v. 8, n. 3, p. 303-315, 2005.

MARTINELLI C.D. Petrografia, estrutural e fluidos da mineralização aurífera dos Araés - Nova Xavantina-MT. Rio Claro, 1998, Tese (Doutorado em Geociências) - Instituto de Geociências e Ciências Exatas, Universidade Estadual Paulista.

MARTINELLI, C.D. Revisão estratigráfica do extremo leste do estado do Mato Grosso - Brasil. In: Simpósio de Geologia da Amazônia, X, 2007, Porto Velho. Resumos expandidos...Porto Velho: Sociedade brasileira de Geologia - Núcleo Norte, 2007, p. 309-311.

MARTINELLI, C.D.; BATISTA, J.J. Estratigrafia da Sequencia Matavulcanosedimentar dos Araés: Grupo Cuiabá. In: Simpósio de Geologia do Centro-Oeste, VII, 2003, Cuiabá. Resumos...Cuiabá: Sociedade brasileira de Geologia - Núcleo Centro-Oeste, 2003, p. 124-126.

MENEZES, R.G. \& SILVA, G.D. Minas de Calcário Agrícola e Áreas Potenciais para Insumos Minerais Agrícolas. In: LIMA, T.M.; MENEZES, R.G.; SILVA, G. D.; BAHIA, R.B.C.; SOUZA JÚNIOR, L. C.; RESENDE, Á.V.; MARTINS, E.S.; SAES, G.S.; PINHO, F.E.C.; NEDER, R.D.; SANTOS, A.A.; SANTOS JÚNIOR, W.A.; GOMES, L.P.; SILVA, S.N.; ORMOND, M.M.; GANZER, E.B.; FALEIRO, A. S.G.; JOSÉ, M.R.; MUNIZ, D.H.F.; FREITAS, L.L. \& PINHEIRO, J.M. Avaliação de Rochas Calcárias e Fosfatadas para Insumos Agrícolas do Estado de Mato Grosso. Cuiabá: Programa Geologia do Brasil-Avaliação de Recursos Minerais do Brasil, p. 57-62., 2008.
MEERT, J. G. A synopsis of events related to the assembly of eastern Gondwana. Tectonophysics, v. 362, p. 1-40, 2003.

PIMENTEL, M.M. \& FUCK, R.A. Neoproterozoic crustal accretion in central Brazil. Geology, V. 20, p. 375-379, 1992.

PINHO, F.E.C. Estudo das rochas encaixantes e veios mineralizados a ouro do Grupo Cuiabá, na região denominada "Garimpo dos Araés" Nova Xavantina, estado de Mato Grosso. Porto Alegre, 1990, 114p., Dissertação (Mestrado em Geoquímica) - Centro de Pesquisas em Geociências, Universidade Federal do Rio Grande do Sul.

SILVA, M. F. Aerogeofísica, Litogeoquímica e Geologia na Caracterização do Rifte Intracontinental da Faixa Paraguai. Brasília, 2007, 117 p., Dissertação (Mestrado) - Instituto de Geociências. Universidade de Brasília.

SOCIO, A.M. Mapeamento Geológico da Fazenda Aráes na região de Nova Xavantina, leste de Mato Grosso. Cuiabá, 2009. 59p, Trabalho de Conclusão de Curso (Graduação em Geologia), Faculdade de Geociências, Universidade Federal de Mato Grosso.

SOUSA, M.F. DE. Mapeamento Geológico na escala 1:60.000, na região de Nova Xavantina, centro-leste do estado de Mato Grosso. 2010. 1 v. Trabalho de conclusão de curso. Curso de Graduação em Geologia. Universidade Federal de Mato Grosso,

TOKASHIKI, C.C.; SAES, G.S. Revisão estratigráfica e faciologica do Grupo Cuiabá no alinhamento Cangas-Poconé, Baixada Cuiabana, Mato Grosso. Revista Brasileira de Geociências, v. 4, p. 661-675, 2008.

TUCKER, M. E. Sedimentary Petrology: an Introduction to the Origin of Sedimentary Rocks. Oxford: Blackwell Science, 260 p., 1991.

VALERIANO, C.M.; PIMENTEL, M. M.; HEILBRON, M.; ALMEIDA, J.C.H.; TROUW, R.A.J. Tectonic evolution of the Bras1 'lia Belt, Central Brazil, and early assembly of Gondwana. In: PANKHURST, R. J., TROUW, R. A. J., BRITO NEVES, B. B. \& DE WIT, M. J. (eds) West Gondwana: PreCenozoic Correlations Across the South Atlantic Region. Geological Society, London, Special Publications, p. 197-210, 2008. Aceito em 10 de maio de 2019 